\title{
COLLEGE OF PHYSIOTHERAPISTS OF SOUTH AFRICA
}

\section{$S$ H Inwin-Camuthers}

The Inaugural Meeting of the College of Physiotherapists of South Africa was held at the Holiday Inn, Pretoria, on 26 April 1991.

Eighteen of the twenty-three Founder Members who had accepted nomination were able to be present. The Meeting was officially opened by the Interim Chairman, Miss S Irwin-Carruthers.

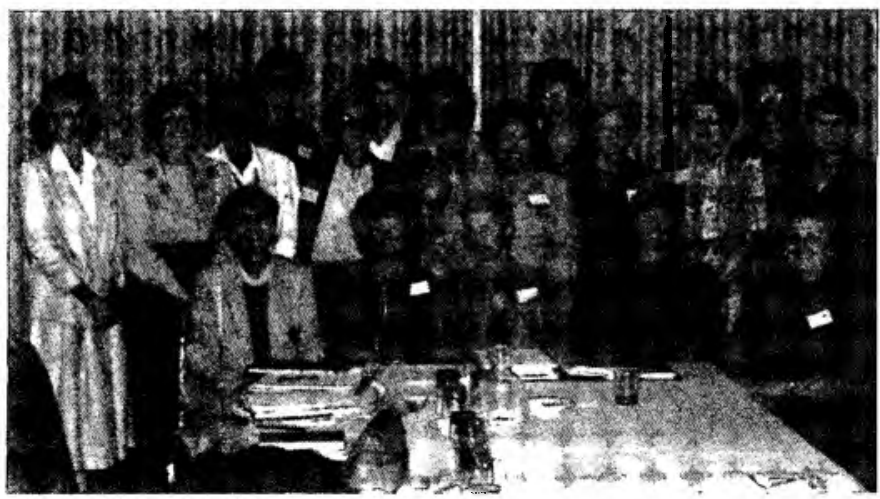

INAUGURAL MEETING

Front row: Jo Beenhakker, Joyce Morton, Sheena IrwinCarruthers, Helen David, Narina Gilder

Middle row: Audrey Weiner, Louise Hack, Katio

Schooman, Lyn Davids, Frances Glauber,Sheila Blackwood, Carol Cunningham, Tiney Krause

Back row: Mariëtte Uys, Marge Steffen, Slelie Eales, Margle Pretorius, Murlel Goodman. Council:

The following ten Founders were elected to the first College

Professor J Beenhakker, Professor P Bowerbank, Mrs C Cunningham, Miss L Davids, Mrs C Eales, Mrs J A C Gilder, Mrs F
Glauber, Professor M Goodman, Miss S Irwin-Carruthers, Mrs M Steffen.

The first meeting of the College Council was held in Johannesburg on 3 June 1991. At this meeting, Professor M Goodman was elected as President of the College. The following Office Bearers were also elected: Miss S Irwin-Carnuthers and Professor J Beenhakker (Vice-Presidents), Mrs M Steffen (Hon Treasurer), Mrs C Cunningham (Hon Registrar) and Mrs $C$ Eales (Chairman of the Examination and Credentials Committee).

A Finance and General Purposes Committee and an Examinations and Credentials Committee were also appointed.

A poster depicting the structure of both the College and the specialisation process was on display during Congress this year, and the Memorandum, Articles of Association and By-Laws of the College are available for inspection at the SASP offices. The primary objectives of the College, set out in the Memorandum, are:

- to encourage advanced study in physiotherapy, to promote the highest degree of clinical skill and efficiency in practive, and to cultivate and maintain the highest ethical standards of professional practice

- to promote and encourage research in physiotherapy.

In the two years preceding the Inaugural Meeting, Interim Specialty Boards had worked on criteria for specialisation in several of the envisaged specialty fields, namely orthopaedic manipulative therapy, cardiopulmonary rehabilitation, obstetric and gynaecological physiotherapy and paediatric neurodevelopmental therapy. A considerable amount of work has been done, and this will be passed onto the Specialty Boards which were appointed at the first meeting of the college Council. When the Specialty Boards are satisfied with their proposals the criteria will be correlated by the Examination and Credentials Committee in order to establish uniform standards.

Information regarding application for admission to the specialisation process will be published in the Journal as soon as this is finalised. So far everything has proceeded according to schedule, and there seems no reason why the College should not be inviting candidates for registration for the specialisation process as from January 1992 , as originally planned. 4

- Miss Sheena Irwin-Carruthers, University of Stellenbosch

\begin{abstract}
...continued from page 47
components are explained in much more detail diagrammatically. Evaluation procedures are described for each component to be assessed. Only once all this relevant information has been gathered it is possible to formulate a management program to address the problems of the patient as a whole. This incorporates much more
\end{abstract} than just treating the patient's symptoms.

REHABILITATION NEEDS FOR PEOPLE WITH LOCOMOTOR DISABILITIES IN MITCHELL'S PLAIN

\section{by $L T$ Coetzee}

Biomedical Engineering University of Cape Town

During 1990 a disability survey was undertaken in Mitchell's Plain, a dormitory town $20 \mathrm{~km}$ from Cape Town. The objective of this descriptive study was to obtain a profile of locomotor disabled people and to determine their rehabilitation needs.

577 households were selected in a community based proportional stratified cluster sample. Data collection took place in two phases. During phase 1 a household census was conducted and screening questions were used to identify disabled people. Occupational and physiotherapy assistants served as interviewers and administered a pretested questionnaire. In phase 2 all locomotor disabled adults identified in phase 1 were interviewed in detail by a physiotherapist. Children identified during phase 1 were transported to a central venue for a medical and developmental assessment.

The overall response rate of $82 \%$ yielded a sample of 2424 people. $312(12.19 \%)$ reported one or more impairment, of which $88 \%$ of the adults and $71 \%$ of the children were further assessed in phase 2.42 $(1.8 \%)$ of the adult sample were found to have disabilities related to locomotion, and $17(41.5 \%)$ of these were in need of assistive devices. 20 people with locomotor disabilities received physiotherapy on first becoming disabled - of these 10 were never followed-up; 6 had no follow up visit in the past 3 years, and 3 had irregular visits in the past 3 years. None of the locomotor disabled people had appointments with paramedical health professionals in the future.

Rehabilitation services in Mitchell's Plain are not accessible to the population and more appropriate rehabilitation methods, particularly for the locomotor disabled, need to be developed. 


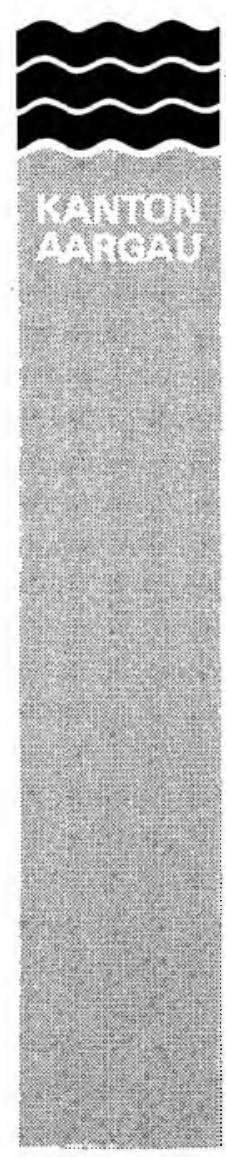

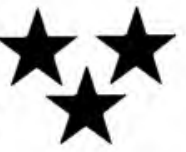

Kantonsspltal

Aarau

Schweiz

Um unser Team zu vervollständigen suchen wir zum baldmōglichen Eintritt

\section{Dipl. Physiotherapeuten/innen} (Krankengymnasten/innen)

welche bereits über einige Berufserfahrung verfügen und die gewillt sind. ihren Beruf mit Freude und Einsatz auszuüben.

Wir sind gerne bereit, Ihnen schriftlich oder telefonisch auf all lhre Fragen, sei es bezügiich Arbeitszeit, Einsatzmōglichkeiten, usw. Auskunft zu geben. Ihre telefonischen Anfragen werden über die Nummer 064/21 4141 an uns weitergeleitet.

Ihre schriftliche Bewerbung mit den üblichen Unterlagen richten Sie bitte an Verwaltung Kantonsspital Aarau $\mathrm{CH}-5001$ Aarau/Schweiz

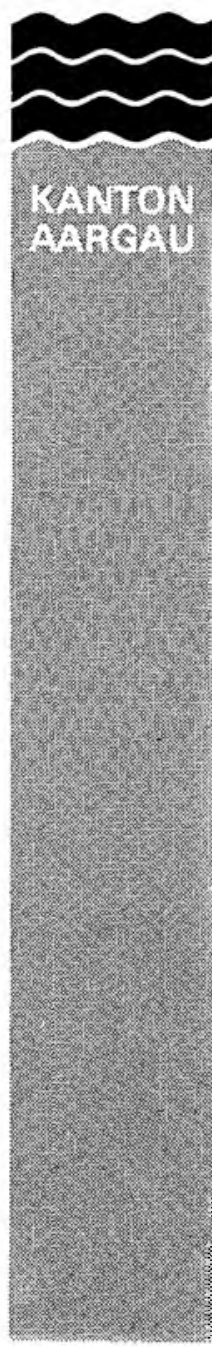

\section{*}

KANTONSSPITAL AARAU SCHWEIZ

Sind Sie jung und möchten Sie die Welt kennenlernen, so hätten Sie dazu eine Chance bei uns in der Schweiz.

Wir suchen zur Vervollständigung unseres Teams

\section{DIPL. \\ PHYSIOTHERAPEUTEN/IN- NEN}

mit positiver Lebenseinstellung, die bereits über einige Berufserfahrung verfügen und die gewillt sind, während mindestens einem Jahr bei uns zu arbeiten.

Haben Sie Interesse, so senden Sie bitte Ihre Bewerbung an das Personalbüro des Kantonsspitals Aarau, $\mathrm{CH}-5001$ Aarau. Auch sind wir gerne bereit Ihnen telefonisch Auskunft zu erteilen (064//21 41 41).

VERWALTUNG KANTONSSPITAL AARAU

CH-5001 A A R A U/Schweiz

\section{PHYSIOTHERAPISTS \\ WORK IN THE UNITED STATES}

We handle all Licensure and Visa paperwork.

Minimum commitment of one year required.

Write or phone collect:

THERAPY RESOURCE NETWORK

P O Box 5430355 N Main Street

Plymouth, MI 48170, USA

091 (313) $455-6660$

\section{PHYSIOTHERAPY DEPARTMENT}

Vacancies exist for clinical tutors and lecturers, full time and part-time, in the salary range of $R 35,808$ to $R 59,910$, to join in the challenging, stimulating and rewarding work of this department. Successful applicants will be expected to participate in management, planning, clinical work, research as well as teaching.

For further information, contact Prof M Goodman, Department of Physiotherapy, Medical School, York Road, Parktown 2193, or phone (011) $488-3450 / 1$

\section{WITS UNIVERSITY}

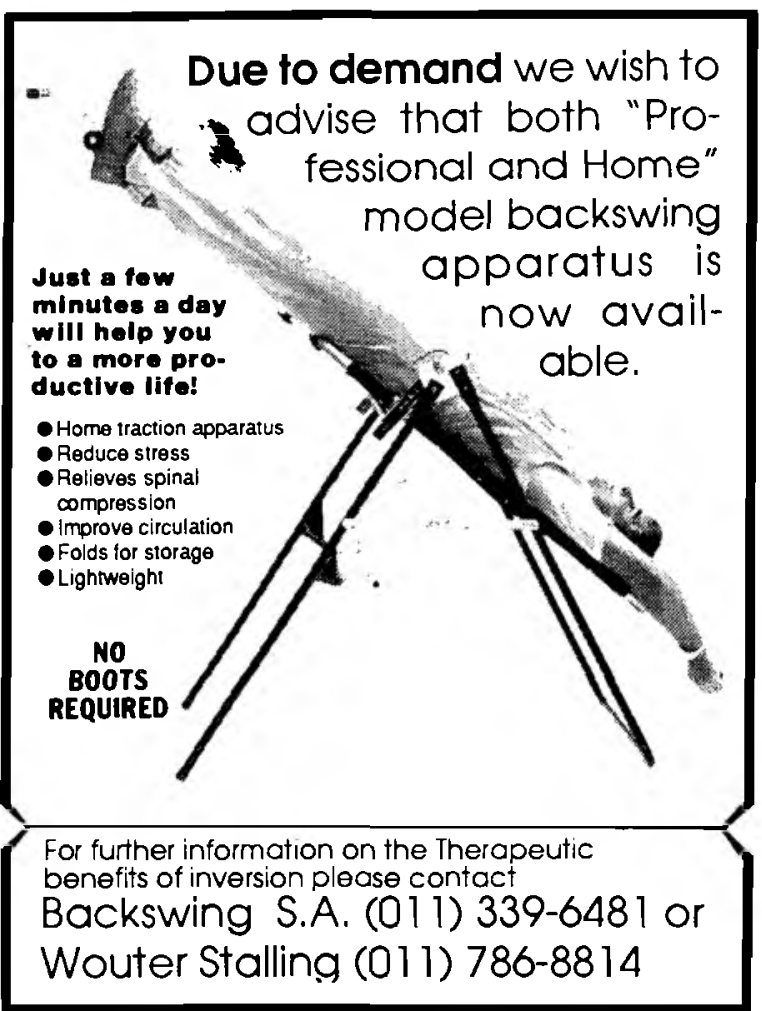

